Article

\title{
Unique Bee Communities within Vacant Lots and Urban Farms Result from Variation in Surrounding Urbanization Intensity
}

\author{
Frances S. Sivakoff ${ }^{(\mathcal{D}}$, Scott P. Prajzner and Mary M. Gardiner *(i) \\ Department of Entomology, The Ohio State University, 2021 Coffey Road, Columbus, OH 43210, USA; \\ sivakoff.3@osu.edu (F.S.S.); prajzner.1@buckeyemail.osu.edu (S.P.P.) \\ * Correspondence: gardiner.29@osu.edu; Tel.: +1-330-601-6628
}

Received: 1 May 2018; Accepted: 5 June 2018; Published: 8 June 2018

\begin{abstract}
We investigated the relative importance of vacant lot and urban farm habitat features and their surrounding landscape context on bee community richness, abundance, composition, and resource use patterns. Three years of pan trap collections from 16 sites yielded a rich assemblage of bees from vacant lots and urban farms, with 98 species documented. We collected a greater bee abundance from vacant lots, and the two forms of greenspace supported significantly different bee communities. Plant-pollinator networks constructed from floral visitation observations revealed that, while the average number of bees utilizing available resources, niche breadth, and niche overlap were similar, the composition of floral resources and common foragers varied by habitat type. Finally, we found that the proportion of impervious surface and number of greenspace patches in the surrounding landscape strongly influenced bee assemblages. At a local scale (100 m radius), patch isolation appeared to limit colonization of vacant lots and urban farms. However, at a larger landscape scale (1000 $\mathrm{m}$ radius), increasing urbanization resulted in a greater concentration of bees utilizing vacant lots and urban farms, illustrating that maintaining greenspaces provides important habitat, even within highly developed landscapes.
\end{abstract}

Keywords: shrinking city; pollinator; urban agriculture; bee conservation; green infrastructure

\section{Introduction}

Urban greenspaces, once disregarded as homogeneous habitat dominated by a few, often invasive, species, are increasingly considered as potential habitat for species conservation [1,2]. Part of their potential stems from the fact that urban greenspaces often support a high species richness that can include rare plants and animals [3-5]. Urban agroecosystems, which contain a diversity of plants reliant on insect-mediate ecosystem services like pollination, are especially promising habitats for pollinator conservation [6,7]. These agroecosystems are often transformed from vacant lots, which can themselves be valuable habitats for bees [2] and biodiversity more broadly [6,8-11]. Urban agroecosystems and vacant lots differ in their management and floral composition, both of which are important drivers of species abundance and richness [11,12]. At the same time, both of these habitat types are located within the urban landscape that can act as a strong environmental filter for communities [13]. Understanding how both the landscape context and the local design and management decisions ongoing within vacant lots and urban agroecosystems act to filter a city's bee community is key to incorporating conservation into urban greenspace planning [14,15].

The landscape structure surrounding an urban greenspace can strongly influence conservation-driven management outcomes. Habitat fragmentation and loss that result from urbanization are known contributors to patterns of species richness and abundance across rural 
to urban gradients [16,17]. At the same time, landscape features at the city-wide scale can act as strong environmental filters, influencing if taxa from a given species pool are able to colonize distinct greenspace patches [12]. For instance, isolation from other greenspaces can lead to reduced bee species richness within urban forest fragments [18] and connectivity with other greenspaces positively predicts bee abundance on green roofs [19]. In some cases, landscape variables also influence the functional trait distribution found within groups $[17,20]$. For instance, highly fragmented urban landscapes tend to favor smaller species and cavity nesting species [21,22].

At a local scale, species interactions among bees and floral resources can drive patterns of pollinator community assembly [12]. Increasing bee species richness is often linked to floral species richness [23], which frequently increases with the degree of urbanization $[4,24,25]$. Within a city, urban greenspaces offer a varied breadth and quality of dietary resources [12,26-29]. Exotic plant species can make up a substantial portion of the floral resources found in urban areas [30]. Although some exotic species common within vacant lots have been found to be highly attractive [31,32], these resources may also be most suitable for polylectic [33] and/or exotic bees [31]. Urban agroecosystems are likely to have a wider breadth of floral resources, including food crops, native and exotic ornamentals, and many of the same weedy species found in vacant lots. Adding flowering resources, principally native species aimed at supporting pollinators and other beneficial insects, increases available nectar and pollen resources [34] and results in a greater richness and abundance of pollinators within a patch for some [35,36], but not all [37] cases.

Herein, we examine the role of landscape structure on the taxonomic and functional trait distributions of bees among urban greenspaces, and evaluate how the design and management of these habitats influences the richness, abundance, dietary breadth and niche overlap within bee assemblages. Our study was conducted within the city of Cleveland, Ohio, a shrinking city that experienced significant population decline resulting in an overabundance of infrastructure, which was demolished over time resulting in vacant land. Worldwide, over 450 cities have experienced significant population decline, including 59 within the United States [38]. Many of these cities have large holdings of reclaimed greenspace, for instance, Cleveland currently encompasses over 27,000 vacant lots that totals more than 1500 ha. [39]. While the spatial extent of vacant land within shrinking cities represents a potentially important conservation resource, the relative importance of local habitat management and landscape context for structuring bee assemblages is largely unknown. Therefore, our objectives were to: (1) compare the richness, abundance and composition of bees found within vacant lots and urban agroecosystems, (2) determine if the intensity of urbanization surrounding these sites influenced bee assemblages and (3) examine how the conversion of vacant land to urban agriculture influenced foraging patterns, including the dietary breadth and overlap of bee species. Our hypotheses were that (i) urban agroecosystems would support a greater richness of pollinator species as a result of enhanced dietary niche breadth and reduced overlap, and (ii) that densely urbanized landscapes would supply a reduced taxonomic richness, higher proportion of exotic species, reduced average body size, and reduced proportion of ground nesting species relative to cavity nesting species to vacant lots and urban farms.

\section{Methods}

Study sites: We selected eight vacant lots and eight urban community gardens, educational and for-profit farms (hereafter referred to collectively as urban farms) within the city of Cleveland, $\mathrm{OH}$, USA for this study in 2010. Site selection was constrained by the availability of vacant lots and the willingness of urban farm managers to participate. Vacant lots were parcels seeded with a fescue grass seed mixture following the demolition of a single-family structure. These properties were managed by periodic mowing, approximately once per month, by the City of Cleveland Land Bank. Urban farms consisted of six sites managed as learning farms by the Cleveland Botanical Garden, one for-profit farm, and one non-profit community garden. All urban farm sites had been converted from vacant lots and managed for food production for at least two years prior to the beginning of this study. No pesticides 
were used within any vacant lot or urban farm for the duration of the study. Property areas of vacant lots ranged from $843 \mathrm{~m}^{2}$ to $6951 \mathrm{~m}^{2}$ and from $271 \mathrm{~m}^{2}$ to $4614 \mathrm{~m}^{2}$ for urban farms. The distance between neighboring sites varied from $145 \mathrm{~m}$ to $1856 \mathrm{~m}$. Two vacant lots were replaced after the 2010 sampling season: one due to construction of a park on the site, and the other due to repeated vandalism of sampling equipment. One urban farm site was replaced following 2011 data collection due to repeated vandalism of sampling equipment.

Pollinator richness and abundance: We collected bees three times per year during 2010-2012 using pan traps on calm, sunny days. Collections occurred in early, mid, and late summer. Following Droege [40], pan traps consisted of $96 \mathrm{~mL}$ white soufflé cups (Solo cup company, Lake Forest, IL, USA), which we kept white or painted either fluorescent blue or fluorescent yellow (Guerra Paint and Pigment, New York, NY, USA) [40]. We divided sites into four, equally-sized plots and placed one of each color pan trap at the center of each plot $1 \mathrm{~m}$ apart and filled with a $1 \%$ dish soap solution (Dawn@ Proctor and Gamble, Cincinnati, OH, USA). After $48 \mathrm{~h}$, we collected the traps and returned them to the laboratory, where we washed individuals in water and dried them with a blow dryer. We pinned and identified bees to the species level using the Discover Life website [41]. All specimen identifications were verified by either Dr. Jason J. Gibbs (University of Manitoba) or Dr. Sam Droege (USGS Patuxent Wildlife Research Center). We deposited voucher specimens in the C.A. Triplehorn Insect Collection within the Museum of Biological Diversity at The Ohio State University.

Bee functional traits: To each individual collected in a pan trap that could be identified to species, we assigned three functional traits: origin, nesting guild, and body length. The origin of each individual was classified as either native or exotic to the United States. Nesting guild assignment was modified from [42] to include: CARPENTER (excavator in woody substrate), MINER (excavator in the ground), NONEST (cleptoparasitic), PITH (nests in pithy stems of plants), and RENT (nests in pre-existing cavities). We used the Discover Life website [41] to determine a mean body length (we calculated the mean of the reported male and female body length) for each species. Measurements were not available for 15 species collected as part of our study, so we measured collected specimens (five individuals per species, unless fewer were collected) and calculated a mean body length.

Resource use: To determine patterns of resource use, we measured floral visitation in 2011 and 2014 within the urban farms and vacant lot sites. Depending on weather conditions, we visited site on a weekly or bi-weekly basis from 20th May to 14th August in 2011, and from 3rd June to 5th August in 2014. As urban farms and vacant lots are heterogeneous habitats, we felt that timed plant species-specific sampling was more appropriate than using transects [43]. Thus, we identified all flowering plant species in bloom within a site and observed blooms of each species for $10 \mathrm{~min}$. For each plant species, the observer either monitored blooms on one or more plants within a $1 \mathrm{~m}^{2}$ area for $10 \mathrm{~min}$, or if multiple patches were present, the observation time was split and two or more $1 \mathrm{~m}^{2}$ patches were observed. During each observation period, we collected any bee that landed on an open flower within the observation area using "insect vacuums" (BioQuip Products, Compton, CA, USA). We then pinned and identified each individual in the same manner as described for specimen collected in pan traps.

Landscape classification: To examine the effect of landscape structure on bee assemblages and patterns of floral resource use, we quantified the landscape surrounding each site using remotely sensed images at 1-2 m resolution [44-46]. We used eCognition Developer 8.7 (Trimble, Westminster, CO, USA) and ArcGIS 10.1 (ESRI, Redlands, CA, USA) for land cover identification and landscape composition analysis, respectively $[47,48]$. We classified land cover into four categories: buildings, pavement, fine vegetation (grasses and low-growing forbs), and coarse vegetation (trees and woody shrubs). From these data, we calculated the following predictor variables: proportion impervious surface (area of buildings and pavement), number of buildings, and number of distinct greenspace patches. We measured these variables within circular buffers with radii of $100 \mathrm{~m}$ and $1000 \mathrm{~m}$ surrounding each site. We selected these scales to measure how local land use $(100 \mathrm{~m})$ as well as larger-scale landscape heterogeneity and urbanization $(1000 \mathrm{~m})$ influence bee species assemblages. 
Statistical analysis: We used generalized linear models to examine the relationship between bee communities and local and landscape factors in R 3.4.3 [49]. All models initially included the fixed effect of habitat type (urban farm or vacant lot), and the following predictor variables at both the local $(100 \mathrm{~m})$ and landscape $(1000 \mathrm{~m})$ scale: the proportion of impervious surface, the number of buildings, and the number of distinct greenspace patches. Collinearity analyses revealed a strong correlation between the number of buildings at $1000 \mathrm{~m}$ and other landscape variables. As a result, we removed this variable from the analysis. All models also included interactions between habitat type and each of the landscape variables. We pooled data across years and collection time periods. Additionally, because the number of pan traps collected at each site varied due to loss and vandalism (median $=78$, $\min =45, \max =94$ collected), we included the number of pan traps per site as an offset in all models. Models evaluating count data (e.g., abundance and richness) were first fit with a Poisson distribution. If we detected overdispersion, we refit models using a negative binomial generalized linear model with the glm.nb function. Models analyzing mean body length were assessed for normality and analyzed using the glm function. We then used backwards model selection with the step function to determine the optimal fixed effects structure for each model. Finally, if we detected a significant interaction between habitat type and a continuous predictor variable, we evaluated whether the slope for either habitat type was significantly different from zero by manually computing the slopes, standard errors, and resulting $p$-values.

To determine if resource use differed between habitat types and across landscape structure, we used generalized linear mixed models in the lme4 package [50] to analyze the abundance and richness of the bee communities visiting flowers at each site. Models included the same fixed effects as those used to analyze pan trap data, and we included the time observing a particular floral resource as an offset and site as a random effect. Similar to the pan trap analysis, we first fit models with a Poisson distribution using the glmer function and then with a negative binomial distribution using the glmer.nb function if we detected overdispersion. We determined the optimal fixed effects structure for each model using the drop1 function for backwards model selection and assessed the significance of interaction slopes by manually computing the slopes, standard errors, and resulting $p$-values for both habitat types. We analyzed differences in community composition using non-metric multidimensional scaling and analysis of similarities using the metaMDS and adonis functions in the vegan package [51].

Network analysis: To describe the plant-pollinator networks at each site, we used the networklevel function in the bipartite package $[52,53]$ to calculate the following indices: (i) generality: the mean number of plant species per pollinator, and (ii) niche overlap: the mean similarity in interaction patterns between pollinators. Because network indices are sensitive to web dimension and sampling intensity [53], we calculated 1000 null models for each web using the nullmodel function with the 'r2dtable' method [52] and corrected our index values as $z$-scores. For a given index, the $z$-score was calculated as the raw score minus the mean index score from the null models divided by the standard deviation of the null models. As in Dormann et al. [54], we then determined whether a given score was significantly different from the mean null model $z$-score using the number of cases where a null model's score was greater than or equal to the observed value. Finally, we used $t$-tests to compare corrected indies from vacant lots and urban farms to determine if patterns in these networks differed between habitat types.

\section{Results}

We collected a total of 2733 bees from pan traps, identifying 2671 of those individuals to species. Overall, we collected bees from 98 species across five families (Table 1). The five most abundant species collected were Agapostemon virescens, Halictus ligatus, Ceratina calcarata, Halictus confusus, and Melissodes bimaculatus. The majority of individuals found occupying urban farms and vacant lots were in the MINER nesting guild, representing $82 \%$ of all individuals (Table 1$)$. Insufficient numbers and representation by the CARPENTER ( $<1 \%$ of individuals), NONEST ( $<1 \%$ of individuals), and PITH ( $6 \%$ of all individuals) nesting guilds across sites prompted us to remove these guilds 
from further analysis. Exotic species represented $8 \%$ of the collected bee fauna, with 208 individuals belonging to 10 species (Table 1). These species included the first known North American collection of Hylaeus pictipes; one specimen was collected from a vacant lot site annually in 2010, 2011, and 2012. Nest parasites represented $14 \%$ of collected species with 14 unique species found.

Table 1. Species list of the bee fauna collected from pan traps within urban farms and vacant lots. We list the total number of specimens of each species collected over the 2010-2012 sampling period as well as the assigned nesting guild (modified from [41]), status in North America, and mean body size.

\begin{tabular}{|c|c|c|c|c|c|c|}
\hline Family & Species & Urban Farms & Vacant Lots & Nesting Guild & Status & Size $(\mathrm{mm})$ \\
\hline \multirow[t]{12}{*}{ Andrenidae } & Andrena barbilabris & 0 & 1 & MINER & Native & 10.50 \\
\hline & Andrena commoda & 4 & 19 & MINER & Native & 11.00 \\
\hline & Andrena cressonii & 1 & 3 & MINER & Native & 9.50 \\
\hline & Andrena dunningi & 1 & 0 & MINER & Native & 11.50 \\
\hline & Andrena erigeniae & 3 & 2 & MINER & Native & 7.50 \\
\hline & Andrena miserabilis & 3 & 0 & MINER & Native & 7.60 \\
\hline & Andrena nasonii & 5 & 0 & MINER & Native & 7.50 \\
\hline & Andrena perplexa & 0 & 2 & MINER & Native & 12.00 \\
\hline & Andrena violae & 0 & 9 & MINER & Native & 10.00 \\
\hline & Andrena wilkella & 2 & 3 & MINER & Exotic & 10.50 \\
\hline & Andrena ziziae & 0 & 1 & MINER & Native & 6.00 \\
\hline & Calliopsis andreniformis & 4 & 15 & MINER & Native & 6.50 \\
\hline \multirow[t]{24}{*}{ Apidae } & Anthophora terminalis & 1 & 1 & MINER & Native & 11.75 \\
\hline & Apis mellifera & 40 & 35 & RENT & Exotic & 13.50 \\
\hline & Bombus fervidus & 3 & 13 & RENT & Native & 10.50 \\
\hline & Bombus griseocollis & 4 & 4 & RENT & Native & 13.75 \\
\hline & Bombus impatiens & 15 & 2 & RENT & Native & 12.25 \\
\hline & Bombus perplexus & 0 & 1 & RENT & Native & 13.00 \\
\hline & Bombus vagans & 0 & 1 & RENT & Native & 10.75 \\
\hline & Ceratina calcarata & 43 & 107 & PITH & Native & 6.50 \\
\hline & Ceratina mikmaqi & 0 & 2 & PITH & Native & 6.50 \\
\hline & Ceratina strenua & 0 & 1 & PITH & Native & 5.50 \\
\hline & Holcopasites calliopsidis & 1 & 0 & NONEST & Native & 5.50 \\
\hline & Melissodes bimaculatus & 70 & 49 & MINER & Native & 13.00 \\
\hline & Melissodes druriellus & 0 & 1 & MINER & Native & 9.90 \\
\hline & Melissodes trinodis & 1 & 2 & MINER & Native & 10.50 \\
\hline & Nomada articulata & 1 & 2 & NONEST & Native & 9.00 \\
\hline & Nomada bidentate group & 1 & 1 & NONEST & Native & 7.35 \\
\hline & Nomada cressonii & 0 & 1 & NONEST & Native & 7.50 \\
\hline & Nomada imbricata & 1 & 0 & NONEST & Native & 9.50 \\
\hline & Nomada luteoloides & 1 & 2 & NONEST & Native & 7.00 \\
\hline & Nomada maculata & 1 & 0 & NONEST & Native & 9.75 \\
\hline & Nomada pygmaea & 0 & 1 & NONEST & Native & 7.25 \\
\hline & Peponapis pruinosa & 25 & 34 & MINER & Native & 12.49 \\
\hline & Triepeolus remigatus & 0 & 1 & NONEST & Native & 13.00 \\
\hline & Xylocopa virginica & 3 & 5 & CARPENTER & Native & 20.00 \\
\hline \multirow[t]{5}{*}{ Colletidae } & Hylaeus affinis & 0 & 5 & RENT & Native & 5.50 \\
\hline & Hylaeus affinis/modestus & 0 & 5 & RENT & Native & 5.75 \\
\hline & Hylaeus hyalinatus & 12 & 7 & RENT & Exotic & 5.89 \\
\hline & Hylaeus modestus & 0 & 2 & RENT & Native & 5.75 \\
\hline & Hylaeus pictipes & 0 & 3 & RENT & Exotic & 4.35 \\
\hline \multirow[t]{24}{*}{ Halictidae } & Agapostemon sericeus & 12 & 20 & MINER & Native & 9.41 \\
\hline & Agapostemon texanus & 39 & 61 & MINER & Native & 10.00 \\
\hline & Agapostemon virescens & 279 & 436 & MINER & Native & 10.50 \\
\hline & Augochlora pura & 1 & 6 & RENT & Native & 8.00 \\
\hline & Augochlorella aurata & 10 & 22 & MINER & Native & 5.25 \\
\hline & Halictus confusus & 38 & 82 & MINER & Native & 7.00 \\
\hline & Halictus ligatus & 65 & 109 & MINER & Native & 8.50 \\
\hline & Halictus rubicundus & 0 & 2 & MINER & Native & 10.50 \\
\hline & Lasioglossum admirandum & 11 & 5 & MINER & Native & 5.25 \\
\hline & Lasioglossum anomalum & 11 & 0 & MINER & Native & 4.00 \\
\hline & Lasioglossum apocyni & 0 & 1 & MINER & Native & 4.56 \\
\hline & Lasioglossum bruneri & 5 & 5 & MINER & Native & 6.30 \\
\hline & Lasioglossum cattellae & 0 & 6 & MINER & Native & 5.10 \\
\hline & Lasioglossum cinctipes & 0 & 1 & MINER & Native & 8.00 \\
\hline & Lasioglossum coeruleum & 6 & 5 & MINER & Native & 6.18 \\
\hline & Lasioglossum cressonii & 0 & 2 & MINER & Native & 5.96 \\
\hline & Lasioglossum ellisiae & 3 & 3 & MINER & Native & 4.32 \\
\hline & Lasioglossum ephialtum & 54 & 28 & MINER & Native & 5.31 \\
\hline & Lasioglossum hitchensi & 23 & 40 & MINER & Native & 4.85 \\
\hline & Lasioglossum illinoense & 5 & 4 & MINER & Native & 4.70 \\
\hline & Lasioglossum imitatum & 39 & 45 & MINER & Native & 4.18 \\
\hline & Lasioglossum laevissimum & 2 & 14 & MINER & Native & 6.11 \\
\hline & Lasioglossum leucocomum & 19 & 55 & MINER & Native & 5.43 \\
\hline & Lasioglossum leucozonium & 17 & 74 & MINER & Native & 7.50 \\
\hline
\end{tabular}


Table 1. Cont.

\begin{tabular}{|c|c|c|c|c|c|c|}
\hline Family & Species & Urban Farms & Vacant Lots & Nesting Guild & Status & Size $(\mathrm{mm})$ \\
\hline & Lasioglossum lineatulum & 2 & 6 & MINER & Native & 6.00 \\
\hline & Lasioglossum lionotum & 0 & 1 & MINER & Native & 4.30 \\
\hline & Lasioglossum pectorale & 24 & 26 & MINER & Native & 5.50 \\
\hline & Lasioglossum pilosum & $\begin{array}{l}24 \\
65\end{array}$ & 53 & MINER & Native & 6.00 \\
\hline & Lasioglossum subviridatum & 1 & 24 & MINER & Native & 10.79 \\
\hline & Lasioglossum tegulare & 10 & 3 & MINER & Native & 8.30 \\
\hline & Lasioglossum versatum & 1 & 2 & MINER & Native & 5.92 \\
\hline & Lasioglossum weemsi & 8 & 8 & MINER & Native & 9.14 \\
\hline & Lasioglossum zephyrum & 4 & 2 & MINER & Native & 6.08 \\
\hline & Lasioglossum zonulum & 0 & 2 & MINER & Native & 7.50 \\
\hline & Sphecodes atlantis & 0 & 1 & NONEST & Native & 5.63 \\
\hline & Sphecodes coronus & 1 & 1 & NONEST & Native & 5.85 \\
\hline & Sphecodes cressonii & 2 & 1 & NONEST & Native & 5.25 \\
\hline & Sphecodes mandibularis & 3 & 0 & NONEST & Native & 5.36 \\
\hline & Sphecodes minor & 0 & 1 & NONEST & Native & 6.75 \\
\hline \multirow[t]{19}{*}{ Megachilidae } & Anthidium manicatum & 1 & 1 & MINER & Exotic & 14.00 \\
\hline & Anthidium oblongatum & 1 & 22 & MINER & Exotic & 8.55 \\
\hline & Megachile apicalis & 2 & 0 & RENT & Exotic & 7.50 \\
\hline & Megachile brevis & 1 & 0 & RENT & Native & 9.50 \\
\hline & Megachile centuncularis & 1 & 3 & RENT & Native & 9.50 \\
\hline & Megachile frigida & 1 & 0 & RENT & Native & 13.00 \\
\hline & Megachile mendica & 2 & 3 & RENT & Native & 10.50 \\
\hline & Megachile pugnata & 0 & 1 & RENT & Native & 14.50 \\
\hline & Megachile relativa & 0 & 1 & RENT & Native & 10.00 \\
\hline & Megachile rotundata & 12 & 28 & RENT & Exotic & 8.00 \\
\hline & Megachile texana & 1 & 2 & RENT & Native & 12.00 \\
\hline & Osmia atriventris & 0 & 1 & RENT & Native & 7.50 \\
\hline & Osmia bucephala & 1 & 1 & RENT & Native & 14.50 \\
\hline & Osmia caerulescens & 4 & 33 & RENT & Exotic & 10.00 \\
\hline & Osmia georgica & 9 & 13 & RENT & Native & 8.25 \\
\hline & Osmia pumila & 3 & 14 & RENT & Native & 7.50 \\
\hline & Osmia subfasciata & 1 & 0 & RENT & Native & 7.50 \\
\hline & Osmia taurus & 2 & 0 & RENT & Exotic & 11.10 \\
\hline & TOTAL & 1048 & 1623 & & & \\
\hline
\end{tabular}

Bee composition, richness, and abundance: The composition of bee species collected from pan traps within vacant lots versus urban farms was significantly different $(\mathrm{F}=2.06, p=0.001$, Figure 1$)$. We found that total abundance $(z=-2.16, p=0.03)$ and native abundance $(z=-2.72, p=0.02)$ of bees collected per pan trap was greater in vacant lots versus urban farms. Bee abundance $(z=3.32, p<0.001)$ and native bee abundance $(z=3.11, p=0.002)$ were also negatively correlated with the proportion of impervious surface present within a $100 \mathrm{~m}$ radius of our study sites. The opposite pattern was found at $1000 \mathrm{~m}$, with bee abundance $(\mathrm{z}=2.41, p=0.02)$ and native bee abundance $(\mathrm{z}=2.12, p=0.03)$ increasing with the proportion of impervious surface in the surrounding landscape.

We found significant interactions between habitat type and landscape variables for exotic bee abundance and bee species richness. For exotic bee abundance, we found a significant interaction between habitat type and the number of greenspaces $(z=-2.53, p=0.01)$ at a $1000 \mathrm{~m}$ radius. Exotic bee abundance in vacant lots was negatively correlated with the number of greenspace patches present at $1000 \mathrm{~m}(\mathrm{t}=-3.06, p=0.01)$, but no such relationship existed for urban farms $(\mathrm{t}=0.85$, $p=0.42$ ) (Figure 2A). We also found a significant interaction between habitat type and the proportion of impervious surface $(z=-3.48, p=0.001)$, where exotic bee abundance in urban farms $(t=3.60, p=0.01)$, but not vacant lots $(\mathrm{t}=-1.49, p=0.17)$, was positively correlated to the proportion of impervious surface present at $1000 \mathrm{~m}$ (Figure 2B). Exotic bee abundance within both habitats was also positively correlated with the number of buildings at $100 \mathrm{~m}(\mathrm{z}=2.04, p=0.04)$. For bee species richness, we found a significant interaction between habitat and the proportion of impervious surface at $1000 \mathrm{~m}(\mathrm{z}=-3.33$, $p=0.001)$, with richness increasing significantly in urban farms $(\mathrm{t}=2.45, p=0.03)$, but not in vacant lots $(\mathrm{t}=-2.17, p=0.06)$, with greater impervious surface in the surrounding landscape at a radius of $1000 \mathrm{~m}$ (Figure 2C). Within both vacant lots and urban farms, the number of greenspace patches in the surrounding landscape was positively correlated with bee richness at a $100 \mathrm{~m}$ radius $(\mathrm{z}=2.09, p=0.04)$ and negatively correlated at $1000 \mathrm{~m}(\mathrm{z}=-2.02, p=0.04)$. 


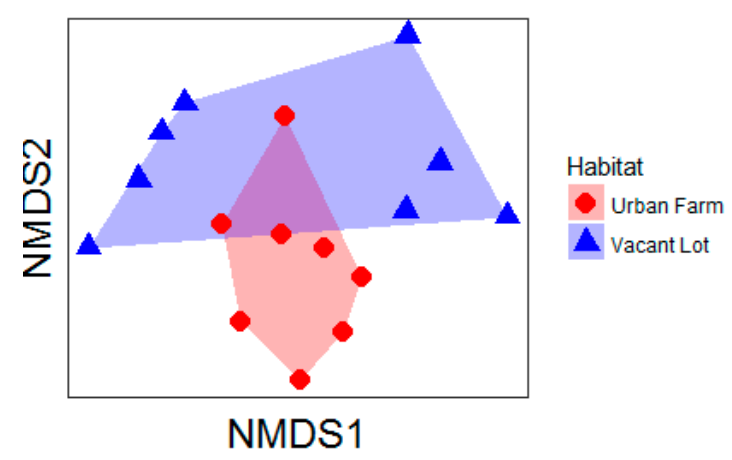

Figure 1. Non-metric multidimensional scaling ordination of the community composition of bees collected from urban farm and vacant lot greenspaces. Stress of the final configuration was acceptable (stress $=0.19$ ) and the ordination was plotted in two dimensions.

Bee functional trait distributions: We found a marginally significant difference in the abundance of bees in the MINER nesting guild among habitats $(z=-1.80, p=0.07)$, with these ground nesting species being less frequently collected from urban farms. Within both vacant lots and urban farms, the abundance of MINER bees decreased with the proportion of impervious surface within $100 \mathrm{~m}$ and increased with the proportion of impervious surface within $1000 \mathrm{~m}$ of research sites. For the RENT nesting guild, we found a significant interaction between habitat type and the proportion of impervious surface at $1000 \mathrm{~m}(\mathrm{z}=-2.66, p=0.01)$, with the abundance of the RENT guild within urban farms increased significantly with the proportion of impervious surface $(t=2.40, p=0.05)$. We did not detect a relationship between RENT abundance within vacant lots and the proportion of impervious surface at $1000 \mathrm{~m}(\mathrm{t}=-1.27, p=0.25)$ (Figure 2D). For mean body size, we found a significant interaction between habitat and the number of buildings within $100 \mathrm{~m}$ of a focal site $(\mathrm{z}=-2.65, p=0.04)$, with an increasing relationship found in urban farms $(\mathrm{t}=2.98, p=0.02)$ and no relationship found in vacant lots $(\mathrm{t}=0.66, p=0.54)$ (Figure 2E).

Bee foraging patterns: Across 2011 and 2014, the number of bee species observed visiting available floral resources ranged from 5-22 per site. Plants with the most visits per 10-min observation were milkweed (Asclepias syriaca; mean $=2.0$ visits $/ 10 \mathrm{~min}$ ), chives (Allium schoenoprasum; mean $=1.8$ visits $/ 10 \mathrm{~min}$ ), and squash (Cucurbita pepo; mean $=1.8$ visits $/ 10 \mathrm{~min}$ ) in urban farms and red clover (Trifolium pretense; mean $=2.4$ visits $/ 10 \mathrm{~min}$ ), white clover (Trifolium repens; mean $=2.2$ visits $/ 10 \mathrm{~min}$ ), and Queen Anne's lace (Daucus carota; mean $=2.1$ visits $/ 10 \mathrm{~min}$ ) in vacant lots (Figure 3). The most commonly observed bees were squash bees (Peponapis pruinosa; mean $=1.9$ observations $/ 10 \mathrm{~min}$ ), honey bees (Apis mellifera; mean = 1.4 observations $/ 10 \mathrm{~min}$ ), and European wool carder bees (Anthidium.manicatum; mean $=1.2$ observations $/ 10 \mathrm{~min}$ ) in urban farms and common eastern bumble bees (Bombus impatiens; mean $=2.3$ observations $/ 10 \mathrm{~min}$ ), a species of mining bee (Calliopsis andreniformis; mean $=2.0$ observations $/ 10 \mathrm{~min}$ ), and honey bees (Apis mellifera; mean $=1.5$ observations/10 $\mathrm{min}$ ) in vacant lots (Figure 3). 

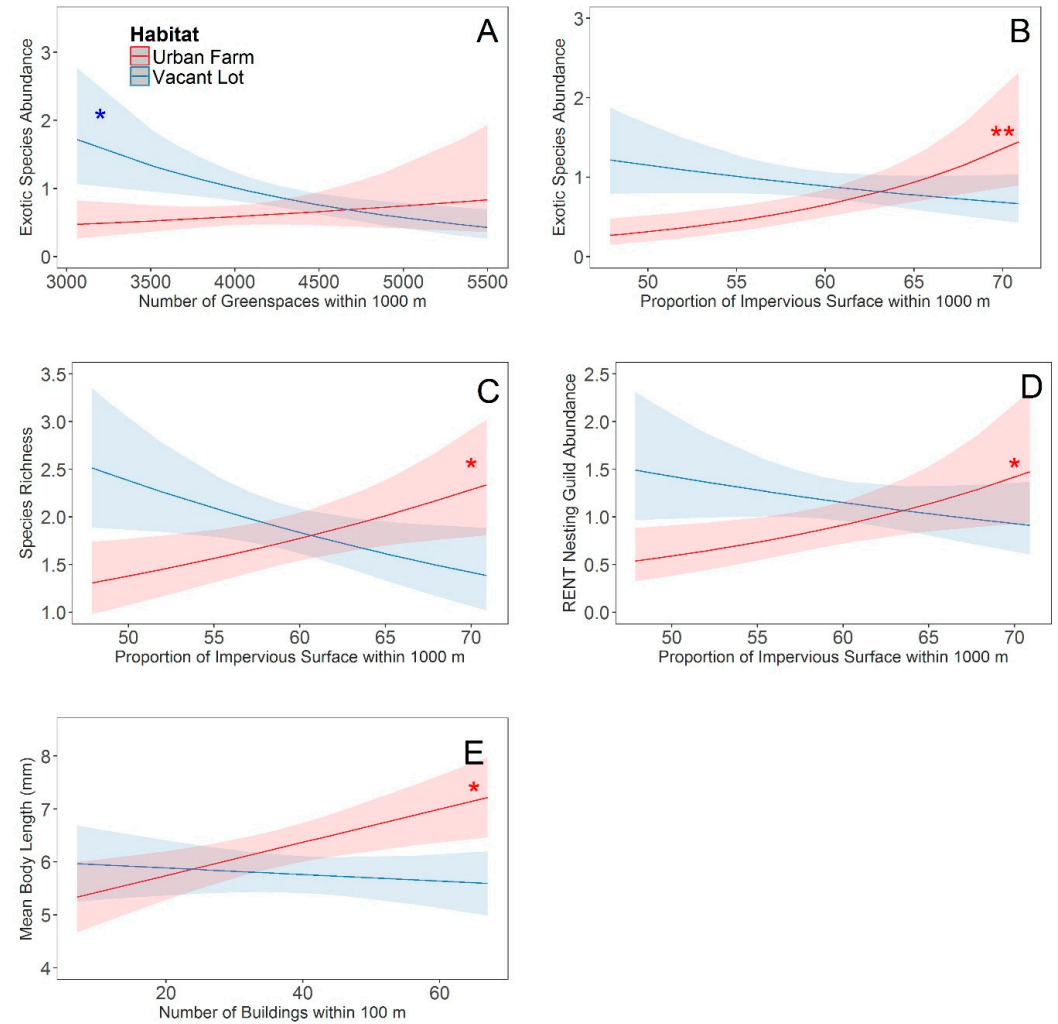

Figure 2. Habitat specific effects of landscape variables. Relationship between exotic bee abundance and (A) the number of greenspace patches, or (B) the proportion of impervious surface within 1000 $\mathrm{m}$ of a focal site. Relationship between $(\mathrm{C})$ bee species richness and the proportion of impervious surface within $1000 \mathrm{~m}$ of a focal site, (D) the abundance of the RENT nesting guild and the proportion of impervious surface within $1000 \mathrm{~m}$ of a focal site, and (E) the mean body length and the number of buildings within a $100 \mathrm{~m}$ radius. Best fit lines ( $\pm 95 \%$ confidence interval) for urban farms are represented in red and vacant lots are represented in blue. An asterisk next to the best fit line indicates that the slope of that line is significantly $\left({ }^{*} p<0.05 ;{ }^{* *} p<0.01\right)$ different from zero.

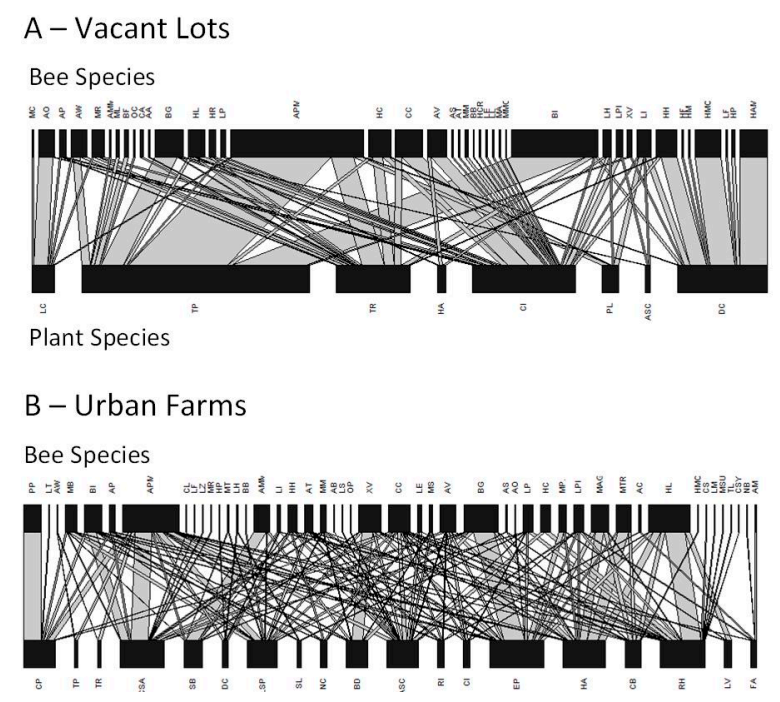

Figure 3. Quantitative plant-pollinator networks in (A) vacant lots and (B) urban farms. Pollinators are represented along the top, plants along the bottom. Each species is represented by a black rectangle, and the width of that rectangle illustrates that relative frequency that a particular species interacts with a member of the opposite trophic level. A list of the full species names is provided in Appendix A: Tables A1 and A2. 
There was no difference in the breadth of floral visitation among habitats (generality, $t=-1.27$, $p=0.23$ ) or the extent of overlap in resource use (niche overlap, $t=0.59, p=0.57$ ). The number of bees observed visiting floral resources per 10-min observation period did not differ among urban farms and vacant lots and was not influenced by landscape variables. In contrast, both overall species richness and native species richness were influenced by landscape variables. As these responses were virtually identical, we report only the results from native species richness. Within both vacant lots and urban farms, species richness of native bee floral visitors per $10 \mathrm{~min}$ was negatively correlated with the proportion of impervious surface in the surrounding landscape at $100 \mathrm{~m}(\mathrm{z}=-2.07, p=0.04)$. We found a significant interaction between habitat type and the number of greenspaces in the surrounding landscape at $100 \mathrm{~m}(\mathrm{z}=2.32, p=0.02)$, with a significant negative relationship between the number of greenspaces and native visitor species richness in urban farms $(t=-2.27, p=0.04)$ but no such relationship existed for vacant lots $(t=0.49, p=0.63)$ (Figure 4). There was also a significant interaction between habitat and the number of greenspaces at $1000 \mathrm{~m}(\mathrm{z}=-2.65, p=0.01)$, with the native species richness of bees collected per $10 \mathrm{~min}$ in urban farms increasing with the number of greenspaces $(t=2.98$, $p=0.01)$ but not in vacant lots $(t=0.10, p=0.92)$ (Figure 4$)$.
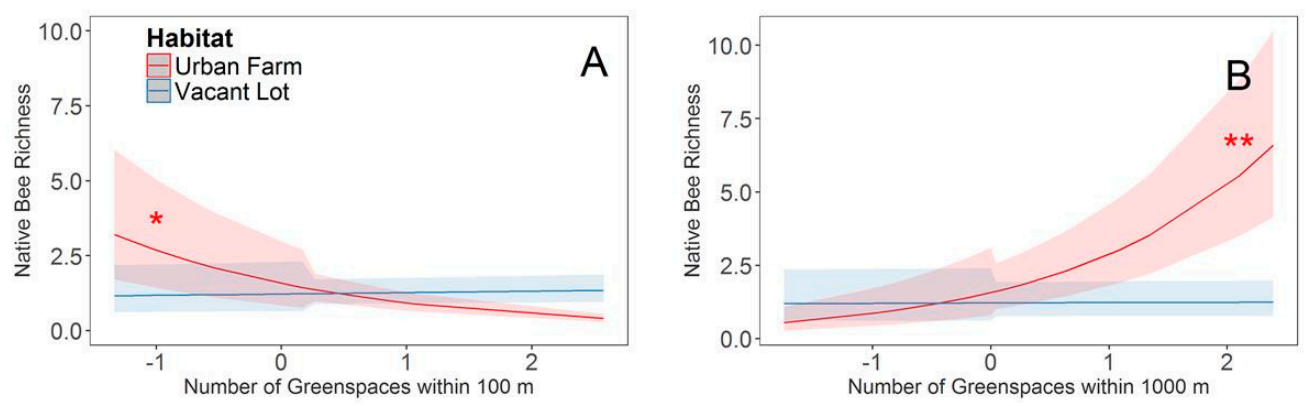

Figure 4. Habitat specific relationship between native species richness and the number of greenspaces within (A) $100 \mathrm{~m}$ and (B) $1000 \mathrm{~m}$ radii. Predictor variables were scaled to ensure model convergence. Best fit lines ( $\pm 95 \%$ confidence interval) for urban farms are represented in red and vacant lots are represented in blue. An asterisk next to the best fit line indicates that the slope of that line is significantly $\left({ }^{*} p<0.05 ;{ }^{* *} p<0.01\right)$ different from zero.

\section{Discussion}

A meaningful shift to value historically overlooked urban habitats as resources for conservation has occurred [2,55]. This is especially true within shrinking cities, where thousands of minimally-managed vacant lots present a vast opportunity to conserve species and deliver needed ecosystem services such as local cooling, carbon sequestration, storm water infiltration and local food production $[2,6,10,56]$. Ideally, managing urban greenspaces for species conservation promotes the provisioning of ecosystem services, but in reality this is hardly a causal relationship. Understanding how to design urban greenspaces to achieve these distinct goals presents a challenge to conservation practitioners [57]. In this study, we examined how transforming vacant land into urban agroecosystems influenced bee assemblages and their foraging patterns. Furthermore, we measured if surrounding urbanization both locally (100 m radius) and at a larger landscape scale (1000 m radius) altered the conservation potential of these two types of urban greenspaces.

Urban greenspaces have repeatedly demonstrated an ability to support a high bee richness [12,24,35,58,59], and arthropod assemblages often vary among distinct forms of greenspace within an urban landscape [11,59-61]. In total, we documented 98 bee species, with the MINER nesting guild dominating both habitat assemblages. We also found 14 unique species within the NO NEST guild ( $14 \%$ of bee species); these nest parasites can be an indicator of habitat quality and their presence has been noted to promote community stability by influencing competition among hosts and reducing dominance of common species [62]. We found that vacant lots and urban farms supported significantly 
different bee assemblages, with 14 species unique to urban farms and 29 species collected solely from vacant lots. We also found a higher abundance of bees within vacant lots versus urban farms. This was due in part to a marginally significant reduction in the MINER guild within urban farm sites, $66.7 \%$ fewer individuals from 34 species were collected relative to vacant lots. Interestingly, communal and eusocial species [63-65] such as A. virescens, H. ligatus, H. confusus, and L. leucocomum were among the most common MINER species collected within vacant lots, and a $36-65 \%$ reduction in the collection of these species was found within urban farms. Frequent soil disturbances resulting from tillage, weeding, irrigation, and mulching practices within urban farms may discourage the establishment and impact the survival of mining species in general and could have a particularly negative influence on communal and eusocial species. Given the nesting behavior of these species, small-scale disturbances such as tillage of a single bed could remove several females and their offspring from a local population. Furthermore, the extended gap in time between foundress and worker foraging periods that exists for eusocial species [63] may make these species more likely to be active and negatively impacted when crop management practices occur at their nest site.

We observed floral visitation within both habitats and did not find evidence to support our prediction that differences in bee richness and abundance observed among vacant lots and urban farms was due to variation in dietary niche breadth or overlap. We found no difference in the breadth of floral visitation per bee species (as measured by "generality") or the extent of overlap in resource use among species (described by "niche overlap") within urban farms versus vacant lots. The average number of bees visiting plants during our observation periods was also consistent across habitats. However, vacant lots and urban farms offered different floral resources, possibly contributing to the variation found in bee community composition we observed. For instance, the composition of common foragers utilizing plant resources varied, with only Apis mellifera shared among the three most common species observed visiting flowers in vacant lots and urban farms. Our findings also highlight that a diversity of plant species can contribute to bee conservation in cities. Red and white clover (T. pretense and T. repens) were the most attract plants within vacant lots, demonstrating the role that weedy exotic plants can play in supporting an urban bee species pool $[30,32,66]$ in self-assembled, minimally-managed greenspaces. In urban farms, the most frequently visited plants per observation period included both harvestable crops and ornamental flowers. These findings support recommendations directed at large-scale rural agroecosystems, suggesting that bee conservation in agricultural habitats could be aided by practices such as the establishment of additional floral resources and relaxed weed control measures [67]. Furthermore, variation in visitation frequency among planted ornamental species found in our study and others $[26,27,68,69]$ highlights the importance of plant selection toward the conservation value of gardens and urban agroecosystems. In our study, black-eyed Susan (Rudbeckia hirta), oxeye daisy (Leucanthemum vulgare), and purple coneflower (Echinacea purpurea) received the most visitors per $10 \mathrm{~min}$ observation. Measuring bee visitation rates to inform conservation focused plantings provides important information, for instance, Garbuzov et al. [27] found a 1000-fold difference in attractiveness among plants surveyed in public urban gardens. Similarly, among the 168 plants surveyed in allotment gardens, $50 \%$ of all bumble bee visits were to just 14 species [68].

We predicted that urbanization intensity would negatively impact the abundance and taxonomic richness of bees found within urban greenspaces, which was based on evidence that isolation from natural habitat sources can reduce pollinator abundance, richness, and the provision of pollination services [70,71]. We found support for this prediction within the localized $100 \mathrm{~m}$ radius surrounding a site, with bee abundance and richness generally declining with the proportion of impervious surface and increasing with the number of greenspaces patches surrounding urban farms and vacant lots. The richness of bees observed visiting plants within urban farms and vacant lots also decreased with more localized impervious surface present. Together, these findings suggest that patch isolation due to a high concentration of localized impervious surface may limit greenspace colonization by bees.

However, many of our findings, particularly at the $1000 \mathrm{~m}$ radius scale, are in contrast to our hypothesis that densely urbanized landscapes supply a reduced taxonomic richness, higher proportion 
of exotic species, reduced average body size, and reduced proportion of ground nesting species. Increased impervious surface within $1000 \mathrm{~m}$ of a focal site was positively associated with total bee, native bee, and MINER nesting guild abundance. Total species richness, exotic bee abundance, and RENT nesting guild abundance within urban farms were also positively related to urbanization at a $1000 \mathrm{~m}$ radius scale and average bee body length increased with a greater concentration of buildings surrounding urban farms at $100 \mathrm{~m}$. These findings are contrary to most previous studies who have either found no strong influence of landscape composition $[7,37,72]$ or that amount of impervious surface surrounding greenspaces is negatively correlated with the abundance, and richness of bee species, with ground nesting bees being particularly sensitive [12,73,74]. Furthermore, landscapes with increasing proportions of urban land typically use support assemblages with a smaller average body size [21]. Cavity nesting species are one exception, which have been found to increase with urbanization $[74,75]$ potentially due to human-derived nesting resources such as fences and buildings. Our results are consistent with these findings as RENT nesting guild abundance was positively correlated with the proportion of impervious surface at $1000 \mathrm{~m}$ within urban farm sites.

For most bee species, however, it is unlikely that urbanization intensity actually aids bee conservation. Instead, the large-scale landscape patterns found in our study are more likely due to a concentration effect, wherein a greater proportion of the landscape-scale species pool relies on a specific greenspace patch as a foraging habitat when fewer sites are available [76]. This phenomenon may be most likely to occur in shrinking cities, where the prevalence of minimally-managed vacant lots can maintain a species pool able to concentrate within available greenspace even when the proportion of the landscape composed of impervious surface is high. For instance, at $1000 \mathrm{~m}$, our most densely developed landscape was comprised of $71 \%$ impervious surface, and vacant land made up a considerable portion of the remaining $29 \%$ of available greenspace, which may provide enough habitat to support many urban-adapted bee species. This pattern warrants further study but suggests that, even within highly urbanized landscapes, maintaining vacant land provides a functional habitat with conservation value for bees in shrinking cities.

\section{Conclusions}

In conclusion, our study adds to the growing body of literature advocating for the maintenance of minimally-managed vacant lot habitats as a conservation resource [6,8-11]. These sites support a high pollinator richness and abundance and require relatively little financial investment. Furthermore, a unique bee community is found within vacant lots versus urban farms, illustrating the value in diversifying the design and management of greenspaces in cities to maximize conservation gains and the delivery of ecosystem services. Maintaining vacant lot greenspaces may be most important for bees within highly urbanized landscapes where few foraging patches exist; however, patches surrounded locally by high concentrations of impervious surface may limit colonization and thus not be ideal spaces for focused conservation investment. Finally, the strength and relationship of landscape effects can be habitat dependent; in several cases, we found a significant influence of landscape variables on assemblages within urban gardens, but not vacant lots. This supports the idea that landscape context influences the impact of local-scale management on insect community dynamics [77], a hypothesis that has not been supported in traditional agricultural systems [78].

Author Contributions: S.P.P. and M.M.G. conceived of the study, S.P.P. collected the data, F.S.S. analyzed the data, F.S.S. and M.M.G. wrote the paper.

Acknowledgments: This research was supported with funding from the Urban Long Term Research Area Exploratory Project (NSF-0948985) and the National Science Foundation CAREER DEB Ecosystem Studies Program (CAREER-1253197). Access to our study sites was generously provided by Cleveland Land Bank, The Cleveland Botanical Gardens, Blue Pike Farm, and members of the 47th St. Community Garden. Aid in the collection and processing of samples was given by Jessie Berkowitz, Shelly Satterfield, Kojo Quaye, Shawn Probst, Jarrad Power, Steve Ryan, Paul Joseph and Chelsea Gordon. We thank Jason Gibbs and Sam Droege for verifying our bee identifications. Caitlin Burkman provided the landscape metrics for our analyses.

Conflicts of Interest: The authors declare no conflict of interest. 


\section{Appendix}

Table A1. List of species codes and corresponding scientific names for bee species.

\begin{tabular}{|c|c|c|c|}
\hline Code & Species Name & Nesting Guild ${ }^{a}$ & Origin $^{b}$ \\
\hline AA & Augochlorella aurata & MINER & Native \\
\hline $\mathrm{AB}$ & Andrena barbilobris & MINER & Native \\
\hline $\mathrm{AC}$ & Andrena commoda & MINER & Native \\
\hline $\mathrm{AM}$ & Andrena miserabilis & MINER & Native \\
\hline AMM & Anthidium manicatum & MINER & Exotic \\
\hline $\mathrm{AO}$ & Anthidium oblongatum & MINER & Exotic \\
\hline $\mathrm{AP}$ & Augochlora pura & RENT & Native \\
\hline $\mathrm{APM}$ & Apis mellifera & RENT & Exotic \\
\hline AS & Agapostemon sericeus & MINER & Native \\
\hline AT & Agapostemon texanus & MINER & Native \\
\hline $\mathrm{AV}$ & Agapostemon virescens & MINER & Native \\
\hline AV & Andrena vicina & MINER & Native \\
\hline $\mathrm{AW}$ & Andrena wilkella & MINER & Exotic \\
\hline $\mathrm{BB}$ & Bombus bimaculatus & RENT & Native \\
\hline $\mathrm{BF}$ & Bombus fervidus & RENT & Native \\
\hline BG & Bombus griseocollis & RENT & Native \\
\hline BI & Bombus impatiens & RENT & Native \\
\hline CA & Calliopsis andreniformis & MINER & Native \\
\hline $\mathrm{CC}$ & Ceratina calcarata & PITH & Native \\
\hline $\mathrm{CL}$ & Colletes latitarsis & MINER & Native \\
\hline CS & Ceratina stenua & PITH & Native \\
\hline CSY & Coelioxys sayi & NONEST & Native \\
\hline HAM & Hylaeus addinis/modestus & RENT & Native \\
\hline $\mathrm{HC}$ & Halictus confusus & MINER & Native \\
\hline HCR & Heriades carinata & RENT & Native \\
\hline $\mathrm{HF}$ & Hylaeus fedorica & RENT & Native \\
\hline $\mathrm{HH}$ & Hylaeus hyalinatus & RENT & Exotic \\
\hline HL & Halictus ligatus & MINER & Native \\
\hline $\mathrm{HM}$ & Hylaeus mesillae & RENT & Native \\
\hline $\mathrm{HMO}$ & Hylaeus modestus & RENT & Native \\
\hline $\mathrm{HP}$ & Hylaeus pictipes & RENT & Exotic \\
\hline HR & Halictus rubicundus & MINER & Native \\
\hline $\mathrm{LE}$ & Lasioglossum ephialtum & MINER & Native \\
\hline $\mathrm{LF}$ & Lasioglossum fuscipenne & MINER & Native \\
\hline LH & Lasioglossum hitchensi & MINER & Native \\
\hline LI & Lasioglossum imitatum & MINER & Native \\
\hline LL & Lasioglossum leucozonium & MINER & Native \\
\hline LM & Lasioglossum mendica & MINER & Native \\
\hline LP & Lasioglossum pectorale & MINER & Native \\
\hline LPI & Lasioglossum pilosum & MINER & Native \\
\hline LS & Lasioglossum smilacinae & MINER & Native \\
\hline LT & Lasioglossum tegulare & MINER & Native \\
\hline $\mathrm{LZ}$ & Lasioglossum zonulum & MINER & Native \\
\hline MA & Megachile apicalis & RENT & Exotic \\
\hline MAG & Melissodes agilis & MINER & Native \\
\hline MB & Melissodes bimaculata & MINER & Native \\
\hline $\mathrm{MC}$ & Megachile concinna & RENT & Native \\
\hline ML & Megachile latimanus & RENT & Native \\
\hline MM & Megachile mendica & RENT & Native \\
\hline MMO & Megachile montivaga & RENT & Native \\
\hline
\end{tabular}


Table A1. Cont.

\begin{tabular}{llll}
\hline Code & Species Name & Nesting Guild ${ }^{\text {a }}$ & Origin $^{\mathbf{b}}$ \\
\hline MP & Megachile pugnata & RENT & Native \\
MR & Megachile rotundata & RENT & Exotic \\
MS & Megachile sculpturalis & RENT & Exotic \\
MSU & Melissodes subillatas & MINER & Native \\
MT & Megachile texana & RENT & Native \\
MTR & Melissodes trinodis & MINER & Native \\
NB & Nomada bidentate grp & NONEST & Native \\
OC & Osmia caerulescens & RENT & Exotic \\
OP & Osmia pumila & RENT & Native \\
PP & Peponapis pruinosa & MINER & Native \\
TL & Triepeolus lunatus & NONEST & Native \\
XV & Xylocopa virginica & CARPENTER & Native \\
\hline
\end{tabular}

a Nesting guild: CARPENTER (excavator in woody substrate), NONEST (cleptoparasitic), MINER (excavator in the ground), PITH (nests in pithy stems of plants), and RENT (nests in pre-existing cavities; adapted from modified from [42]). ${ }^{b}$ Origin: native or exotic to the United States.

Table A2. List of species codes and corresponding scientific names for plant species.

\begin{tabular}{lll}
\hline Code & Species Name & Common Name \\
\hline AS & Allium schoenoprasum & Chives \\
ASY & Asclepias syriaca & Common Milkweed \\
BD & Buddleja davidii & Butterfly Bush \\
CB & Cosmos bipinnatus & Cosmos \\
CI & Cichorium intybus & Chicory \\
CP & Cucurbita pepo & Squash \\
CS & Cucumis sativus & Cucumber \\
DC & Daucus carota & Queen Ann's Lace \\
EP & Echinacea purpurea & Purple Coneflower \\
FA & Fragaria x ananassa & Strawberry \\
HA & Helianthus annuus & Sunflower \\
LC & Lotus corniculatus & birds-foot trefoil \\
LS & Lavandula spp. & Lavender \\
LV & Leucanthemum vulgare & Oxeye daisy \\
NC & Nepeta cataria & Catnip \\
PL & Plantago lanceolata & Narrowleaf Plantain \\
RH & Rudbeckia hirta & Black-eyed Susan \\
RI & Rubus idaeus & Raspberry \\
SB & Stachys byzantina & Lamb's Ear \\
SL & Solanum lycopersicum & Tomato \\
TP & Trifolium pratense & Red Clover \\
TR & Trifolium repens & White Clover \\
\hline
\end{tabular}

\section{References}

1. Lepczyk, C.A.; Aronson, M.F.J.; Evans, K.L.; Goddard, M.A.; Lerman, S.B.; MacIvor, J.S. Biodiversity in the City: Fundamental Questions for Understanding the Ecology of Urban Green Spaces for Biodiversity Conservation. BioScience 2017, 67, 799-807. [CrossRef]

2. Hall, D.M.; Camilo, G.R.; Tonietto, R.K.; Ollerton, J.; Ahrné, K.; Arduser, M.; Ascher, J.S.; Baldock, K.C.R.; Fowler, R.; Frankie, G.; et al. The city as a refuge for insect pollinators. Conserv. Biol. 2017, 31, $24-29$. [CrossRef] [PubMed]

3. Aronson, M.F.; La Sorte, F.A.; Nilon, C.H.; Katti, M.; Goddard, M.A.; Lepczyk, C.A.; Warren, P.S.; Williams, N.S.; Cilliers, S.; Clarkson, B. A global analysis of the impacts of urbanization on bird and plant diversity reveals key anthropogenic drivers. Proc. R. Soc. B 2014, 281. [CrossRef] [PubMed] 
4. Banaszak-Cibicka, W.; Ratyńska, H.; Dylewski, L. Features of urban green space favourable for large and diverse bee populations (Hymenoptera: Apoidea: Apiformes). Urban For. Urban Green. 2016, 20, 448-452. [CrossRef]

5. Ives, C.D.; Lentini, P.E.; Threlfall, C.G.; Ikin, K.; Shanahan, D.F.; Garrard, G.E.; Bekessy, S.A.; Fuller, R.A.; Mumaw, L.; Rayner, L. Cities are hotspots for threatened species. Glob. Ecol. Biogeogr. 2016, 25, 117-126. [CrossRef]

6. Gardiner, M.M.; Burkman, C.E.; Prajzner, S.P. The Value of Urban Vacant Land to Support Arthropod Biodiversity and Ecosystem Services. Environ. Entomol. 2013, 42, 1123-1136. [CrossRef] [PubMed]

7. Potter, A.; LeBuhn, G. Pollination service to urban agriculture in San Francisco, CA. Urban Ecosyst. 2015, 18, 885-893. [CrossRef]

8. Burkman, C.E.; Gardiner, M.M. Urban greenspace composition and landscape context influence natural enemy community composition and function. Biol. Control 2014, 75, 58-67. [CrossRef]

9. Gardiner, M.M.; Prajzner, S.P.; Burkman, C.E.; Albro, S.; Grewal, P.S. Vacant land conversion to community gardens: Influences on generalist arthropod predators and biocontrol services in urban greenspaces. Urban Ecosyst. 2014, 17, 101-122. [CrossRef]

10. Riley, C.B.; Herms, D.A.; Gardiner, M.M. Exotic trees contribute to urban forest diversity and ecosystem services in inner-city Cleveland, OH. Urban For. Urban Green. 2018, 29, 367-376. [CrossRef]

11. Delgado de la Flor, Y.A.; Burkman, C.E.; Eldredge, T.K.; Gardiner, M.M. Patch and landscape-scale variables influence the taxonomic and functional composition of beetles in urban greenspaces. Ecosphere 2017, 8, e02007. [CrossRef]

12. McFrederick, Q.S.; LeBuhn, G. Are urban parks refuges for bumble bees Bombus spp. (Hymenoptera: Apidae)? Biol. Conserv. 2006, 129, 372-382. [CrossRef]

13. McKinney, M.L. Urbanization as a major cause of biotic homogenization. Biol. Conserv. 2006, 127, $247-260$. [CrossRef]

14. HilleRisLambers, J.; Adler, P.B.; Harpole, W.S.; Levine, J.M.; Mayfield, M.M. Rethinking Community assembly through the lens of coexistence theory. Annu. Rev. Ecol. Evol. Syst. 2012, 43, 227-248. [CrossRef]

15. Aronson, M.F.; Nilon, C.H.; Lepczyk, C.A.; Parker, T.S.; Warren, P.S.; Cilliers, S.S.; Goddard, M.A.; Hahs, A.K.; Herzog, C.; Katti, M. Hierarchical filters determine community assembly of urban species pools. Ecology 2016, 97, 2952-2963. [CrossRef] [PubMed]

16. McKinney, M.L. Effects of urbanization on species richness: A review of plants and animals. Urban Ecosyst. 2008, 11, 161-176. [CrossRef]

17. Harrison, T.; Winfree, R. Urban drivers of plant-pollinator interactions. Funct. Ecol. 2015, 29, 879-888. [CrossRef]

18. Antonini, Y.; Martins, R.P.; Aguiar, L.M.; Loyola, R.D. Richness, composition and trophic niche of stingless bee assemblages in urban forest remnants. Urban Ecosyst. 2013, 16, 527-541. [CrossRef]

19. Braaker, S.; Ghazoul, J.; Obrist, M.K.; Moretti, M. Habitat connectivity shapes urban arthropod communities: The key role of green roofs. Ecology 2014, 95, 1010-1021. [CrossRef] [PubMed]

20. Quistberg, R.D.; Bichier, P.; Philpott, S.M. Landscape and local correlates of bee abundance and species richness in urban gardens. Environ. Entomol. 2016, 45, 592-601. [CrossRef] [PubMed]

21. Wray, J.C.; Neame, L.A.; Elle, E. Floral resources, body size, and surrounding landscape influence bee community assemblages in oak-savannah fragments. Ecol. Entomol. 2014, 39, 83-93. [CrossRef]

22. Banaszak-Cibicka, W.; Żmihorski, M. Wild bees along an urban gradient: Winners and losers. J. Insect Conserv. 2012, 16, 331-343. [CrossRef]

23. Pardee, G.L.; Philpott, S.M. Native plants are the bee's knees: Local and landscape predictors of bee richness and abundance in backyard gardens. Urban Ecosyst. 2014, 17, 641-659. [CrossRef]

24. Lowenstein, D.M.; Matteson, K.C.; Xiao, I.; Silva, A.M.; Minor, E.S. Humans, bees, and pollination services in the city: The case of Chicago, IL (USA). Biodivers. Conserv. 2014, 23, 2857-2874. [CrossRef]

25. Fischer, L.K.; Eichfeld, J.; Kowarik, I.; Buchholz, S. Disentangling urban habitat and matrix effects on wild bee species. PeerJ 2016, 4, e2729. [CrossRef] [PubMed]

26. Frankie, G.W.; Thorp, R.W.; Pawelek, J.C.; Hernandez, J.; Coville, R. Urban bee diversity in a small residential garden in northern California. J. Hymenopt. Res. 2009, 18, 368-379.

27. Garbuzov, M.; Samuelson, E.E.; Ratnieks, F.L. Survey of insect visitation of ornamental flowers in Southover Grange garden, Lewes, UK. Insect Sci. 2015, 22, 700-705. [CrossRef] [PubMed] 
28. Sikora, A.; Micholap, P.; Kelm, M. Flowering plants preferred by bumblebees (Bombus Latr.) in the botanical garden of medicinal plants in Wroclaw. J. Apic. Sci. 2016, 60, 59-68. [CrossRef]

29. Matteson, K.C.; Grace, J.B.; Minor, E.S. Direct and indirect effects of land use on floral resources and flower-visiting insects across an urban landscape. Oikos 2013, 122, 682-694. [CrossRef]

30. Hinners, S.J.; Hjelmroos-Koski, M.K. Receptiveness of foraging wild bees to exotic landscape elements. Am. Midland Nat. 2009, 162, 253-265. [CrossRef]

31. MacIvor, J.S.; Ruttan, A.; Salehi, B. Exotics on exotics: Pollen analysis of urban bees visiting Sedum on a green roof. Urban Ecosyst. 2015, 18, 419-430. [CrossRef]

32. Larson, J.L.; Kesheimer, A.J.; Potter, D.A. Pollinator assemblages on dandelions and white clover in urban and suburban lawns. J. Insect Conserv. 2014, 18, 863-873. [CrossRef]

33. Hanley, M.E.; Awbi, A.J.; Franco, M. Going native? Flower use by bumblebees in English urban gardens. Ann. Bot. 2014, 113, 799-806. [CrossRef] [PubMed]

34. Hicks, D.M.; Ouvrard, P.; Baldock, K.C.R.; Baude, M.; Goddard, M.A.; Kunin, W.E.; Mitschunas, N.; Memmott, J.; Morse, H.; Nikolitsi, M.; et al. Food for pollinators: Quantifying the nectar and pollen resources of urban flower meadows. PLoS ONE 2016, 11, e0158117. [CrossRef] [PubMed]

35. Frankie, G.W.; Thorp, R.W.; Schindler, M.; Hernandez, J.; Ertter, B.; Rizzardi, M. Ecological patterns of bees and their host ornamental flowers in two northern California cities. J. Kansas Entomol. Soc. 2005, 78, 227-246. [CrossRef]

36. Threlfall, C.G.; Walker, K.; Williams, N.S.; Hahs, A.K.; Mata, L.; Stork, N.; Livesley, S.J. The conservation value of urban green space habitats for Australian native bee communities. Biol. Conserv. 2015, 187, 240-248. [CrossRef]

37. Matteson, K.C.; Langellotto, G.A. Determinates of inner city butterfly and bee species richness. Urban Ecosyst. 2010, 13, 333-347. [CrossRef]

38. Oswalt, P.; Rieniets, T. Atlas of Shrinking Cities; Hatje Cantz: Berlin, Germany, 2006.

39. Greene, J.; Commissioner of Neighborhood Development, Cleveland, OH, USA. Personal communication, 2008.

40. Droege, S. The Very Handy Manual: How to Catch and Identify Bees and Manage a Collection; USGS Bee Inventory and Monitoring Lab, Patuxent Wildlife Research Center: Beltsville, MA, USA, 2009.

41. Ascher, J.S.; Pickering, J. Bee Species Guide (Hymenoptera: Apoidea: Anthophila). Available online: http: / / www.discoverlife.org/mp/20q (accessed on 7 June 2018).

42. Moretti, M.; de Bello, F.; Roberts, S.P.M.; Potts, S.G. Taxonomical vs. functional responses of bee communities to fire in two contrasting climatic regions. J Anim. Ecol. 2009, 78, 98-108. [CrossRef] [PubMed]

43. Gibson, R.H.; Knott, B.; Eberlein, T.; Memmott, J. Sampling method influences the structure of plant-pollinator networks. Oikos 2011, 120, 822-831. [CrossRef]

44. Blaschke, T. Object based image analysis for remote sensing. ISPRS J. Photogramm. Remote Sens. 2010, 65, 2-16. [CrossRef]

45. De Pinho, C.M.D.; Fonseca, L.M.G.; Korting, T.S.; Almeida, C.M.; de Kux, H.J.H. Land-cover classification of an intra-urban environment using high-resolution images and object-based image analysis. Int. J. Remote Sens. 2012, 33, 5973-5995. [CrossRef]

46. Zhou, W.; Troy, A. An object-oriented approach for analysing and characterizing urban landscape at the parcel level. Int. J. Remote Sens. 2008, 29, 3119-3135. [CrossRef]

47. ESRI. ArcGIS Desktop: Release 10.1; Environmental Systems Research Institute: Redlands, CA, USA, 2011.

48. Trimble Documentation. Trimble eCognition Developer 8.7 Reference; Trimble Germany GmbH: Munich, Germany, 2011.

49. R Core Team. R: A Language and Environment for Statistical Computing; R Foundation for Statistical Computing: Vienna, Austria, 2017.

50. Bates, D.; Mächler, M.; Bolker, B.; Walker, S. Fitting linear mixed-effects models using lme4. arXiv, 2014, arXiv:1406.5823

51. Oksanen, J.; Blanchet, F.G.; Kindt, R.; Legendre, P.; O’hara, R.B.; Simpson, G.L.; Solymos, P.; Stevens, M.H.H.; Wagner, H. Vegan: Community Ecology Package. R package Version 1.17-2; R Foundation for Statistical Computing: Vienna, Austria, 2010.

52. Dormann, C.F.; Gruber, B.; Fründ, J. Introducing the bipartite package: Analysing ecological networks. $R$ News 2008, 8, 8-11. 
53. Dormann, C.F.; Fründ, J.; Blüthgen, N.; Gruber, B. Indices, graphs and null models: Analyzing bipartite ecological networks. Open Ecol. J. 2009, 2, 7-24. [CrossRef]

54. Dormann, C.F. How to be a specialist? Quantifying specialisation in pollination networks. Netw. Biol. Hong Kong 2011, 1, 1. [CrossRef]

55. Fortel, L.; Henry, M.; Guilbaud, L.; Guirao, A.L.; Kuhlmann, M.; Mouret, H.; Rollin, O.; Vaissière, B.E. Decreasing abundance, increasing diversity and changing structure of the wild bee community (Hymenoptera: Anthophila) along an urbanization gradient. PLoS ONE 2014, 9, e104679. [CrossRef] [PubMed]

56. Chaffin, B.C.; Shuster, W.D.; Garmestani, A.S.; Furio, B.; Albro, S.L.; Gardiner, M.; Spring, M.; Green, O.O. A tale of two rain gardens: Barriers and bridges to adaptive management of urban stormwater in Cleveland, Ohio. J. Environ. Manag. 2016, 183, 431-441. [CrossRef] [PubMed]

57. Cameron, R.W.; Blanuša, T. Green infrastructure and ecosystem services-is the devil in the detail? Ann. Bot. 2016, 118, 377-391. [CrossRef] [PubMed]

58. Matteson, K.C.; Ascher, J.S.; Langellotto, G.A. Bee richness and abundance in New York City urban gardens. Ann. Entomol. Soc. Am. 2008, 101, 140-150. [CrossRef]

59. Tonietto, R.; Fant, J.; Ascher, J.; Ellis, K.; Larkin, D. A comparison of bee communities of Chicago green roofs, parks and prairies. Landsc. Urban Plan. 2011, 103, 102-108. [CrossRef]

60. Burkman, C.E.; Gardiner, M.M. Spider assemblages within greenspaces of a deindustrialized urban landscape. Urban Ecosyst. 2015, 18, 793-818. [CrossRef]

61. Uno, S.; Cotton, J.; Philpott, S.M. Diversity, abundance, and species composition of ants in urban green spaces. Urban Ecosyst. 2010, 13, 425-441. [CrossRef]

62. Sheffield, C.S.; Pindar, A.; Packer, L.; Kevan, P.G. The potential of cleptoparasitic bees as indicator taxa for assessing bee communities. Apidologie 2013, 44, 501-510. [CrossRef]

63. Richards, M.H.; Packer, L. Annual variation in survival and reproduction of the primitively eusocial sweat bee Halictus ligatus (Hymenoptera: Halictidae). Can. J. Zool. 1995, 73, 933-941. [CrossRef]

64. Gibbs, J.; Brady, S.G.; Kanda, K.; Danforth, B.N. Phylogeny of halictine bees supports a shared origin of eusociality for Halictus and Lasioglossum (Apoidea: Anthophila: Halictidae). Mol. Phylogenet. Evol. 2012, 65, 926-939. [CrossRef] [PubMed]

65. Onuferko, T.M.; Kutby, R.; Richards, M.H. A list of bee species (Hymenoptera: Apoidea) recorded from three municipalities in the Niagara region of Ontario, including a new record of Lasioglossum furunculum Gibbs (Halictidae) in Canada. J. Entomol. Soc. Ont. 2015, 146, 3-22.

66. MacIvor, J.S.; Cabral, J.M.; Packer, L. Pollen specialization by solitary bees in an urban landscape. Urban Ecosyst. 2014, 17, 139-147. [CrossRef]

67. Nicholls, C.I.; Altieri, M.A. Plant biodiversity enhances bees and other insect pollinators in agroecosystems. A review. Agron. Sustain. Dev. 2013, 33, 257-274. [CrossRef]

68. Ahrne, K.; Bengtsson, J.; Elmqvist, T. Bumble bees (Bombus spp.) along a gradient of increasing urbanization. PLoS ONE 2009, 4, e5574. [CrossRef] [PubMed]

69. Garbuzov, M.; Ratnieks, F.L. Quantifying variation among garden plants in attractiveness to bees and other flower-visiting insects. Funct. Ecol. 2014, 28, 364-374. [CrossRef]

70. Ricketts, T.H.; Regetz, J.; Steffan-Dewenter, I.; Cunningham, S.A.; Kremen, C.; Bogdanski, A.; Gemmill-Herren, B.; Greenleaf, S.S.; Klein, A.M.; Mayfield, M.M. Landscape effects on crop pollination services: Are there general patterns? Ecol. Let. 2008, 11, 499-515. [CrossRef] [PubMed]

71. Winfree, R.; Aguilar, R.; Vázquez, D.P.; LeBuhn, G.; Aizen, M.A. A meta-analysis of bees' responses to anthropogenic disturbance. Ecology 2009, 90, 2068-2076. [CrossRef] [PubMed]

72. Williams, N.M.; Winfree, R. Local habitat characteristics but not landscape urbanization drive pollinator visitation and native plant pollination in forest remnants. Biol. Conserv. 2013, 160, 10-18. [CrossRef]

73. Carper, A.L.; Adler, L.S.; Warren, P.S.; Irwin, R.E. Effects of suburbanization on forest bee communities. Environ. Entomol. 2014, 43, 253-262. [CrossRef] [PubMed]

74. Geslin, B.; Oddie, M.; Folschweiller, M.; Legras, G.; Seymour, C.L.; Van Veen, F.F.; Thébault, E. Spatiotemporal changes in flying insect abundance and their functional diversity as a function of distance to natural habitats in a mass flowering crop. Agric. Ecosyst. Environ. 2016, 229, 21-29. [CrossRef]

75. Cane, J.H.; Minckley, R.L.; Kervin, L.J.; Williams, N.M. Complex responses within a desert bee guild (Hymenoptera: Apiformes) to urban habitat fragmentation. Ecol. Appl. 2006, 16, 632-644. [CrossRef] 
76. Veddeler, D.; Klein, A.-M.; Tscharntke, T. Contrasting responses of bee communities to coffee flowering at different spatial scales. Oikos 2006, 112, 594-601. [CrossRef]

77. Concepción, E.D.; Díaz, M.; Baquero, R.A. Effects of landscape complexity on the ecological effectiveness of agri-environment schemes. Landsc. Ecol. 2008, 23, 135-148. [CrossRef]

78. Woltz, J.M.; Isaacs, R.; Landis, D.A. Landscape structure and habitat management differentially influence insect natural enemies in an agricultural landscape. Agric. Ecosyst. Environ. 2012, 152, 40-49. [CrossRef]

(C) 2018 by the authors. Licensee MDPI, Basel, Switzerland. This article is an open access article distributed under the terms and conditions of the Creative Commons Attribution (CC BY) license (http:/ / creativecommons.org/licenses/by/4.0/). 